\title{
Idealisme Seniman Berdampak pada Marginalisasi Kesenian Indang Tradisi
}

\author{
Indrayuda ${ }^{1}$ dan Susmiarti \\ Jurusan Sendratasik, Fakultas Bahasa dan Seni, Universitas Negeri Padang
}

jurnal tari, teater, dan wayang volume 2 number 2 ,

November 2019

page $64-73$

\begin{abstract}
This article aims to reveal and analyze the problem of the artistry of traditional art in Padang Pariaman district. Today the existence of Indang art less popular in the cultural life of the community Padang Pariaman. In turn, Indang art is rarely used and functioned by Padang Pariaman society today. The research was done by explanation method, and the research data is qualitative. Data collected throughout the interview process, observation of socio-cultural symptoms of society, and the existence of Indang. The analysis was done by ethnography approach, by determining component analysis and determining the cultural theme. The result of the research obtained is that the structure and shape of Indang have not changed until now. Indang art form and structure is less suitable to the taste of today's society so that Indang art is less popular to the public for entertainment activities. The activities of artists on stage often disturb the artistic and aesthetic performances, i.e. the artists often create any activities that spoil the atmosphere of the show.
\end{abstract}

Keywords: Indang tradisi; form and structure; ethnographic approach; explanation method

\section{Pendahuluan}

Kesenian tradisional yang terdapat di berbagai nagari di Minangkabau merupakan identitas kultural dari nagari tersebut. Eksistensi dari kesenian tersebut mampu mempopulerkan nagari tersebut kepada dunia luar. Oleh sebab itu, kesenian yang memiliki karakteristik mencerminkan sikap dan perilaku masyarakat nagari yang memilikinya. Kesenian tradisional yang tumbuh di berbagai nagari di Minangkabau, Provinsi Sumatera Barat, merupakan seni kolektif dari perwujudan gagasan dan perilaku sosial masyarakat pemiliknya. Kesenian tersebut menjadi kebanggaan komunitas nagari, dan secara struktur adat mampu melibatkan elit adat dalam pemeliharaan dan perkembangannya, sehingga unsur masyarakat nagari turut memiliki dan merasa bertanggung jawab pada kesenian tersebut.
Hakikatnya, menurut Indrayuda (2012: 89), bahwa seni tradisional Minangkabau yang dibangun dari pikiran kolektif, umumnya menjadi milik masyarakat nagari dan tumbuh berkembang di nagari. Kesenian tersebut dibangun dari gagasan adat salingka nagari, sehingga kesenian tersebut memiliki ciri dari kenagarian tersebut. Selanjutnya, nama dari kesenian tersebut mewakili kenagariannya seperti Rabab Pasisia, Saluang Pauh, Tabuik Pariaman, Talempong Unggan, tari "Mancak Koto Anau", tari "Piriang Lumpo", dan Indang Pariaman. Masing-masing kesenian tersebut adalah kesenian tradisional di Minangkabau yang merupakan ciri khas dari masing-masing nagari dan sekaligus mewakili adat istiadat dari nagari tersebut.

Sebagaimana Andriani (2012: 202) mengatakan bahwa kesenian tradisi merupakan identitas dari suatu suku bangsa. Kesenian tradisi seperti pantun adalah identitas bagi

$1 \quad$ Alamat korespondensi: Universitas Negeri Padang, Jl. Belibis No.21A, Padang, Sumatera Barat. E-mail: indrayudayusuf@yahoo.co.id; susmiartisusmiarti@yahoo.com; HP: 082174343764 
bangsa Melayu. Oleh sebab itu, mengenal bentuk kesenian tradisi berarti mengenal identitas dari suatu suku bangsa. Oleh karena itu, masyarakat Minangkabau di nagari mempertahankan kesenian tradisinya sebagaimana ia mempertahankan identitas budayanya.

Kabupaten Pariaman sebagai sebuah wilayah pemerintahan dan etnik yang terletak di pantai barat Provinsi Sumatera Barat memiliki berbagai seni tradisi yang unik. Kesenian tersebut berasal dari pikiran kolektif masyarakat Pariaman seperti Salawat Dulang, Ulu Ambek, Randai, dan kesenian Indang. Kesenian Indang umumnya hampir terdapat di seluruh nagari di Kabupaten Pariaman. Salah satu bentuk kesenian yang saat ini populer bagi masyarakat luas di Sumatera Barat maupun di luar Sumatera Barat.

Menurut Kamal (2012: 48), masalah kepemilikan tradisi kesenian di Padang Pariaman, baik Luambek maupun Indang, berhubungan langsung dengan struktur sosial adat di nagari (desa). Masyarakatnya memposisikan kesenian tradisi seperti Indang dan Lu Ambek sebagai "suntiang niniak- mamak, pamenan anak mudo-mudo" (perhiasan ninik-mamak atau pimpinan adat, permainan anak muda). Lembaga adat niniak mamak di nagari (desa) yang anggotanya terdiri atas para penghulu suku (pemuka adat) berposisi sebagai pemilik kesenian tradisi. Oleh sebab itu, praktik dalam berkesenian saat ini didelegalisikan kepada para pemuda di nagari atau desa yang telah mendapat pendidikan adat dan agama sebagai syarat menjadi pemain Indang atau Luambek, maksudnya tidak boleh sembarang pemuda sebagai pelaku pertunjukan Luambek dan Indang di Padang Pariaman.

Indang tumbuh dan berkembang di setiap nagari di Kabupaten dan Kota Pariaman sampai saat ini. Merujuk pada posisi kesenian Indang dari dulu sampai sekarang berposisi sebagai sarana dakwah dalam agama Islam, pelengkap upacara adat, dan sebagai sarana hiburan masyarakat yang tampil dalam berbagai kegiatan sosial budaya masyarakat nagarinagari di Pariaman yang mampu mengundang keramaian masyarakat penonton.
Ediwar, Mohamed Anwar Omar Din, dan Zuliyati Zakaria (2010: 229) mengatakan bahwa salah satu ciri seni suku Melayu, seperti Melayu Minangkabau, adalah berbudaya Islam. Seni-seni yang berbudaya Islam merupakan suatu ciri atau identitas dari masyarakat Melayu Minangkabau seperti kesenian Indang yang terdapat di daerah Padang Pariaman. Kesenian Indang dibudayakan seiring dengan masuknya agama Islam ke wilayah Minangkabau. Kesenian Indang pada pada masa lampau awalnya digunakan sebagai media dakwah bagi ulama Minangkabau di Padang Pariaman.

Menurut Ediwar (2010: 51), kesenian Indang merupakan warisan budaya lama dari masyarakat Padang Pariaman. Sebagai warisan budaya lama, kesenian Indang menjadi lambang atau pertanda dari harga diri dan identitas daerah dan budaya masyarakat di Padang Pariaman. Apabila dalam parade kesenian Indang pada kegiatan acara alek nagari terdapat kelompok Indang yang kalah dalam pertunjukan, seluruh masyarakat yang diwakili oleh kelompok Indang tersebut merasa malu. Demikian kukuhnya idealisme masyarakat terhadap keberadaan Indang sebagai identitas daerahnya.

Kesenian Indang atau disebut juga dengan Baindang, salah satu bentuk pertunjukan yang terdiri dari sastra lisan yang berupa syair-syair yang bernafaskan Islam, pada masa lampau digunakan untuk berdakwah, dan didukung oleh permainan rapa'i. Syair yang didendangkan dalam Baindang ini lebih banyak berupa keagungan atau pujian pada Allah, shalawat Nabi, dan hikayat tentang Rasulullah dan Ulil Amri. Namun sekarang telah berkembang berupa pantun yang bersifat spontan yang berperan mengkritik atau menyindir. Secara penampilan kesenian Indang dilakukan dengan duduk ber-shaf. Aktivitas yang dilakukan adalah melantunkan syairsyair dan sedikit menggunakan tubuh untuk bergerak sedangkan aksen dari pertunjukan tersebut, selain dari menggerakan tubuh yang digeser ke kiri dan ke kanan dalam posisi duduk, juga menggunakan telapak tangan untuk memukul rebana kecil (rapa'i). 
Kesenian Baindang tidak seperti seni pertunjukan tari pada umumnya karena dalam penampilanya, Baindang tidak menonjolkan gerakan tubuh penari, melainkan lebih mengedepankan permainan alat musik rapa'i. Pada awalnya, jenis alat musik yang digunakan dalam Baindang adalah rebana. Namun karena ukurannya terlalu besar, rebana diperkecil dan disebut dengan rapa'i yang tujuannya untuk memudahkan para pemain Indang dalam menggunakan atau memainkannya.

Pergerakan arus globalisasi telah merambah ke berbagai sektor kehidupan masyarakat, salah satunya sektor kesenian dan kepariwisataan. Pada kenyataannya, hal tersebut berdampak kepada munculnya sektor industri hiburan dan kepariwisataan di Sumatera Barat. Pertumbuhan industri hiburan telah mendorong munculnya berbagai event organizer dan sanggar-sanggar seni yang muncul di berbagai kota dan kabupaten di Sumatera Barat.

Berawal dari digalakannya industri seni pertunjukan di Sumatera Barat, telah terjadi peta persaingan yang kompetitif antara kesenian tradisional dan kesenian modern atau kesenian kreasi. Kompetisi didasarkan kepada kualitas dan kemasan pertunjukan, inovasi garapan, inovasi bentuk pertunjukan, dan inovasi manajemen seni pertunjukan. Selain itu, persaingan juga didasari oleh inovasi pemasaran. Selain itu, persaingan juga didasarkan kepada aksen dan attitude pelakunya. Artinya, penampilan artis penari dan pemusik juga turut memicu adanya peta persaingan antara seni pertunjukan hiburan di Sumatera Barat saat ini. Peta persaiangan tersebut telah dimulai pada awal tahun 1980an di Sumatera Barat sampai saat ini.

Persaingan yang kompetitif berdampak kepada tersingkirnya bentuk-bentuk kesenian tradisi Minangkabau, seperti kesenian Indang tradisi (Baindang). Keberadaan kesenian Indang tradisi (Baindang) terdesak oleh kesemarakan dan kualitas dari performance seni pertunjukan kreasi, seperti tari kreasi yang banyak diproduksi oleh rumah-rumah produksi di Kota Pariaman dan Kabupaten Pariaman. Akibatnya, kesenian Indang tradisional kekurangan pasar, pasar kesenian Indang tradisional berkisar pada acara alek nagari saja, sekali-kali ditampilkan dalam pesta perkawinan.

Keberadaan kesenian Indang sebagai seni tradisional dari wilayah Pariaman, secara tidak langsung terlindas dari gejolak derasnya arus perubahan terhadap seni pertunjukan di Pariaman. Menyikapi perkembangan seni pertunjukan tersebut, masyarakat Pariaman mulai berpaling dari selera seni tradisional ke modernisasi. Karena dewasa ini, selera masyarakat Pariaman terhadap pertunjukan sarat dengan nilai entertainment (hiburan). Pada gilirannya, berbagai acara kegiatan budaya yang dilaksanakan masyarakat tidak terlepas dari kegiatan seni hiburan.

Idealisme dan fantisme yang berlebihan dari masyarakat pemilik kesenian Indang tradisi telah meminggirkan keberadaan kesenian Indnag dalam Industri hiburan. Artinya akibat dari fanatisme dan idealisme yang berlebihan dari seniman Indang tradisi berdampak pada tersingkirnya keberadaan kesenian tersebut dalam kegiatan industri hiburan di Padang Pariaman dan Suamtera Barat umumnya.

Bertitik tolak dari fenomena yang terjadi pada kesenian Indang tersebut, telah terjadi suatu kemunduran pertunjukan kesenian Indang tradisi sebagai komoditi industri hiburan. Kemunduran ini dampak dari persoalan idealisme dan fanatisme seniman yang berlebihan terhadap kesenian tersebut. Dengan demikian idealisme berpengaruh pada bentuk dan struktur maupun aktivitas seniman dalam pertunjukan kesenian Indang. Artikel ini akan menganalisis bentuk dan struktur yang mapan dan aktivitas seniman yang kurang relevan dengan selera masyarakat masa kini.

\section{Asal Usul Kesenian Indang}

Kesenian tradisional Indang di Pariaman pada awalnya berasal dari India yang dibawa oleh Syech Abdul Kadir yang menyebar ke daerah Aceh. Setelah dari Aceh, kesenian Indang dibawa oleh ulama-ulama Islam terse- 
but ke Pariaman yang pada awalnya di daerah Karan Aur dan kemudian berhenti di Rambai. Menurut Ediwar (2010: 45), salah satu tujuan dibawanya Indang ke Pariaman yaitu sebagai penunjang untuk menyebarkan agama Islam. Karena itu kesenian Indang digunakan sebagai media dakwah dalam penyebaran agama Islam di Pariaman dan sekitarnya.

Seorang tokoh surau di Tanjung Medan Nagari Ulakan, yang bernama Dalin Na'aman mengombinasikan kesenian saman dan didong (dari Aceh) dengan kesenian rebana dan diberinya nama Indang. Penyajiannya dengan menyusun murid-murid secara berderet dalam posisi bersila atau shaf. Mereka menyanyikan riwayat nabi, sifat Tuhan sambil memukul rebana dan melakukan gerakan ke depan, ke belakang, ke kanan, dan ke kiri. Penyajian ini disebut Baindang. Mulai era pembudayaan kesenian ini oleh Dalin Na'aman, kesenian Indang menjadi budaya tradisi masyarakat Paraiman sampai masa kini.

Menurut Efrida (2016: 64) kebudayaan berusaha untuk memahami fakta- fakta sebagai suatu sistem, sebagai kesatuan organik. Sejarah sebuah kebudayaan merupakan titik tolak yang tidak mungkin dihilangkan karena dengan adanya masa lalu, masa sekarang hadir. Masa lalu itu akan penuh dengan nilai dan fungsi yang sesuai dengan zamannya. Oleh sebab itu, asal muasal kesenian Indang dimulai dari sejarah masa lalu, yakni ketika para ulama kembali dari Aceh dan kemudian mengembangkan kesenian yang berpola pada kesenian yang persis sama dengan keseniian dari India, yang menggunakan rebana kecil yang pada gilirannya disebut kesenian Indang.

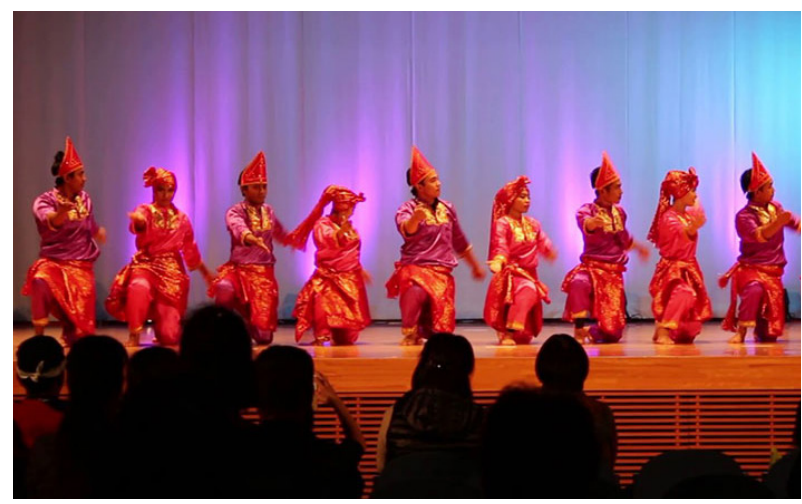

Gambar 1. Tari Indang (Dindin Badindin) asal Minang. (Sumber: http://adat-tradisional.blogspot. com/2016/11/tari-indang-dindin-badindin-asal-minang.html)

Syafril Can dan Ediwar (2010) mengatakan bahwa istilah 'baindang' berasal dari kata 'bendang'yang artinya terang. Istilah ini pada mulanya merupakan sebutan untuk alim ulama yang menerangkan ajaran agama Islam. Awalnya kesenian Indang ini lahir dan berkembang di surau-surau yang dimainkan sesudah mengaji oleh para santri.

Namun seiring berkembangnya zaman, Indang ini disebarkan dari surau ke arena (orang Pariaman memberi istilah dari surau turun ke tanah). Artinya Indang tidak lagi ditampilkan di surau melainkan di tempat terbuka atau yang disebut dengan laga-laga. Oleh karena itu, Indang pun digunakan sebagai media hiburan rakyat sampai saat ini. Indang yang ditampilkan di atas panggung lagalagai ini terus berkembang menjadi budaya masyarakat Padang Pariaman sampai saat ini.

Kesenian Indang (Baindang) ini hanya boleh dimainkan oleh golongan laki-laki saja, hal itu dikarenakan dahulu di Minangkabau biasanya anak laki-laki yang sering tidur di surau, sementara itu kesenian tersebut biasanya juga di lakukan dari habis shalat Isya sampai larut malam di surau atau di lagalaga. Oleh karena itu, tidak memungkinkan kaum perempuan bermain Indang. Kesenian ini dimainkan oleh laki-laki lebih kurang sebanyak 13 orang.

Menurut Syafril Can, dikarenakan oleh kesenian Indang (Baindang) terus membudaya dalam masyarakat Padang Pariaman, Indang menjadi permainan rakyat selain menajdi hiburan rakyat. Bahkan Indang telah berkembang menjadi identitas nagari dan kebanggaan nagari. Oleh sebab itu, terbentuklah berbagai

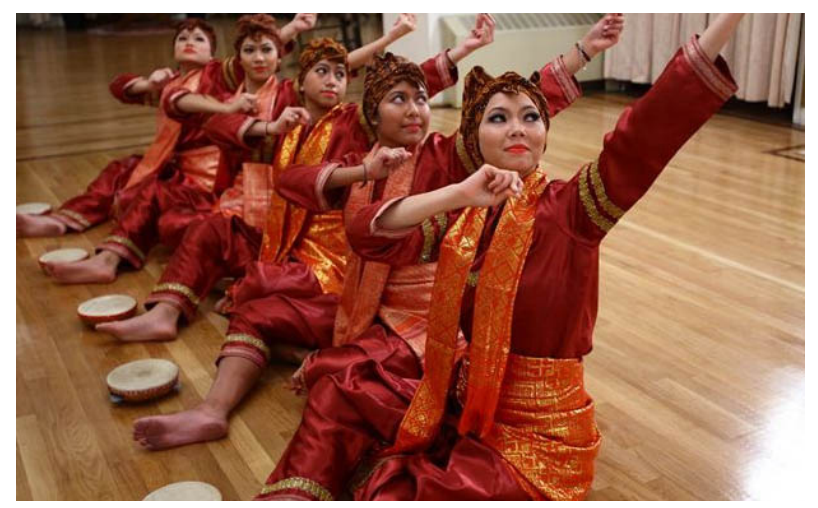
. 
kelompok kesenian Indang. Pada gilirannnya, timbul hasrat dari kelompok ini untuk bersilaturahmi atau saling memperlihatkan ketrampilan Indang dalam sebuah pesta rakyat atau parade unjuk kebolehan baindang, sehingga muncul istilah Indang Tigo Jerong.

\section{Struktur Garapan Kesenian Indang}

Menurut Sari, K. M., Asriati, A., dan Darmawati, D. (2013), struktur dapat diartikan sebagai satuan dari tata hubungan antara bagian- bagian yang terdapat dalam suatu organisasi bentuk karya seni, seperti tari, teater, dan musik. Struktur tersebut terdapat dalam keseluruhan tata hubungan dari karya seni tersebut.

Sementara itu, Martin dan Pesovar (dalam Sari, K. M., Asriati, A., Darmawati, D, 2013: 67) mengatakan morfologi dan struktur, yaitu suatu bangunan dari organik sebuah karya seni yang dianalogikan seperti tari, hanya dapat diungkapkan dengan memisah-misahkan karya seni tersebut ke dalam komponenkomponen yang dikategorikan sebagai bagian dan berikutnya disebut dengan istilah motif. Unit organik terkecil dalam karya seni seperti tari, yaitu unit pola ritme dan kinetik yang membentuk suatu struktur yang secara relatif mirip dan berulang atau muncul kembali.

Merujuk pernyataan Martin dan Pesovar, Ade Suhandra mengatakan bahwa struktur pertunjukan kesenian Indang dimulai dari imbauan, kemudian darak, dan seterusnya penyampaian syair, dan kemudian darak lagi, dan ditutup dengan syair bersamaan dengan

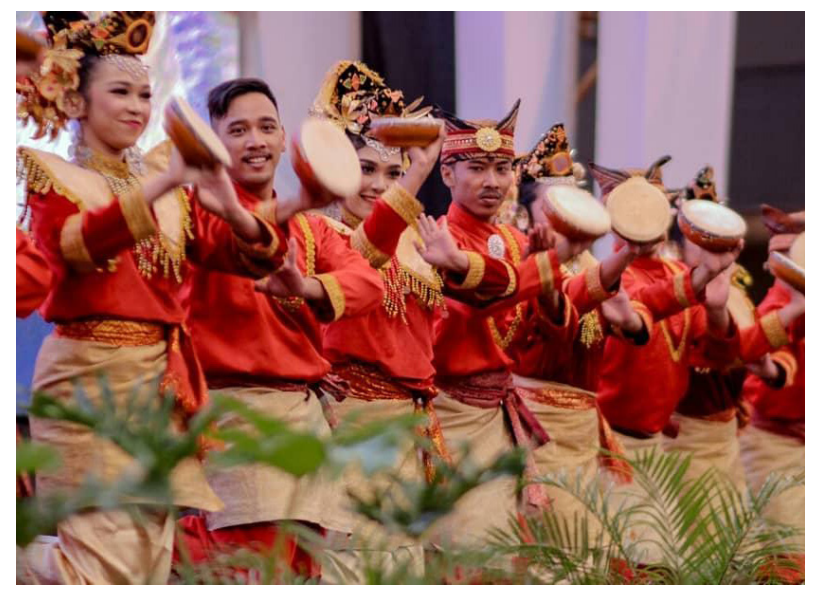

darak indang. Lebih lanjut, Ade Suhandra menjelaskan bahwa struktur kesenian Indang terbentuk dari tata hubungan antara komponen imbauan, darak, pantun, dan gerak yang terdapat dalam bagian introduksi, bagian permulaan, tengah, dan klimaks, serta penyelesaian.

Seiring dengan itu, Juni Amri mengatakan bahwa bagian awal dari pertunjukan Indang dimulai dari minta restu dari niniak mamak, masing-masing kelompok Indang sebelum memulai pertunjukan mereka memohon doa restu lebih dulu kepada Tuo Indang, atau niniak mamak dari kelompok masing-masing. Sebagaimana Bakarudin mengatakan bahwa struktur pertunjukan Indang tersebut dimulai dari imbauan, kemudian darak, dan syair, darak, kemudian syair dan gerak, selanjutnya darak dan syair lagi sebagai penutup. Akan tetapi, bagian awal biasanya setiap kelompok Indang menggunakan imbauan, baru darak sedangkan bagian tengah biasanya bervariasi tergantung pada kemampuan kelompok tersebut menata pertunjukannya.

Tata hubungan sintagmatis merupakan tata hubungan seperti mata rantai yang tidak dapat dipisahkan antara motif satu dengan motif lainnya, sedangkan tata hubungan paradigmatis merupakan tata hubungan yang dapat ditukarbalikkan antara motif satu dengan motif lainnya (Sari, K. M., Asriati, A., dan Darmawati, D, 2013: 69). Berdasarkan analisis peneliti bahwa struktur kesenian Indang terkonstruksi dalam dua bentuk, yaitu pertama, struktur yang seperti mata rantai dan kedua, struktur yang dapat dikombinasikan

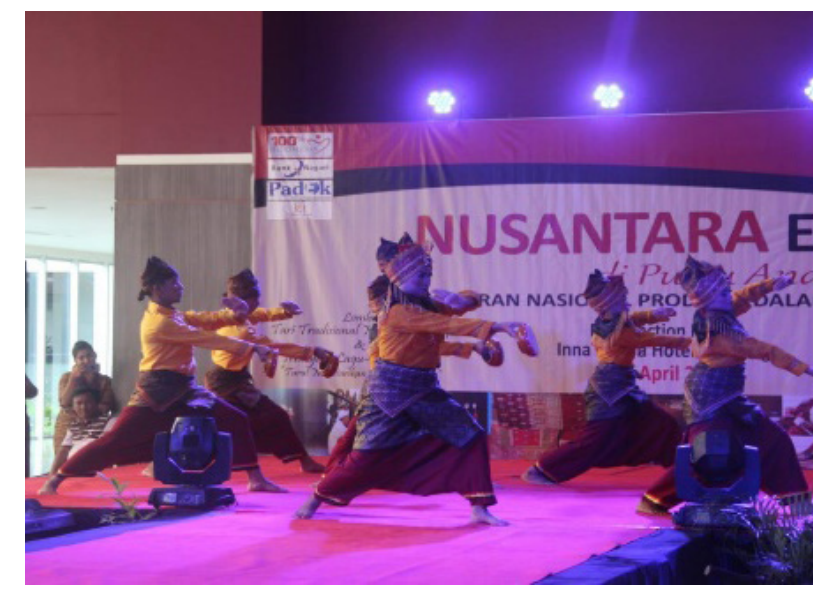

Gambar 2. Tari Indang. (Dokumentasi: Indrayuda) 
letaknya, artinya dapar ditukar letak antara bagian yang satu dengan yang lainnya.

Struktur pertunjukan kesenian Indang secara tradisi introduksi sering diawali dengan imbauan seperti dalam kesenian Ulu Ambek disebut dengan dampiang. Terdapat empat bagian dalam pertunjukan Indang yang sering digunakan oleh kelompok Indang tradisi dari Padang Pariaman ini, yaitu prolog atau introduksi, bagian awal, bagian tengah atau klimaks, dan bagian akhir atau penyelesaian.

Bakarudin mengatakan bahwa struktur pertunjukan Indang meskipun secara garis besar ada empat macam struktur, tetapi ada juga struktur yang di tengah, bagian klimaks diulang kembali, bahkan ada juga dari bagian awal sampai klimaks diulang kembali, dan barulah pertunjukan tersebut berakhir. Hal ini yang terkadang membosankan penonton karena sering mengulang tema-tema yang ada dalam pertunjukan Indang tersebut.

Di dalam karya seni tradisi terdapat struktur yang tersusun dengan alur yang jelas, di dalam struktur juga terdapat substruktur. Tata hubungan antarbagian seperti dalam tari "Wireng" dari Mangkunegaran terdapat struktur yang jelas seperti maju beksan, beksan, mundur beksan. Ketiga struktur tersebut membentuk kesatuan organik dari tari "Wireng". Seperti juga kesenian Indang, terdapat struktur imbauan pada intro; darak dan syair pada bagian tengah; dan darak serta gerak maupun syair bagian klimaks; selanjutnya darak serta syair pada bagian penyelesaian. Terkadang, pengulangan struktur dalam pertunjukan Indang disebabkan oleh waktu yang

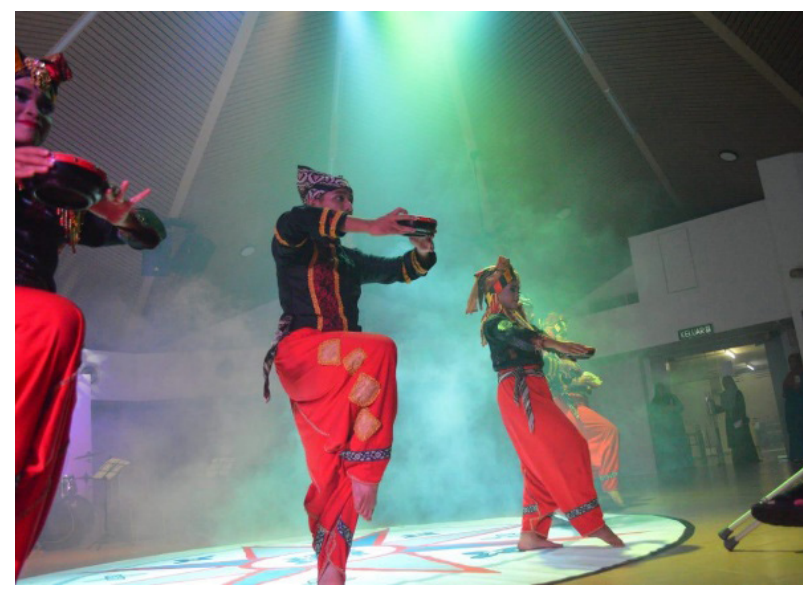

ditetapkan oleh panitia pelaksana alek nagari, atau karena waktu yang belum larut, sementara penonton masih banyak memadati arena pertunjukan.

\section{Bentuk dan Struktur Tari Indang Tradisi Akibat Idealisme Seniman}

Permasalahan pada struktur kesenian Indang adalah bahwa tidak adanya variasi motif gerak, irama, dan melodi serta dinamika dalam bagian perbagian di dalam struktur pertunjukan kesenian Indang tradisi di Padang Pariaman saat ini. Sebagaimana pernyataan Rafiah dalam wawancaranya dengan peneliti tanggal 28 Maret 2017 di Pariaman, Rafiah mengatakan bahwa di dalam struktur garapan Indang, sangat kurang dipertunjukan variasi, sehingga ada pengulangan bagian-bagian di dalam struktur garapan tersebut. Pada gilirannya, pengulangan ini menjadi titik lemah dari nilai estetis pertunjukan Indang bagi masyarakat kekinian.

Rustiyanti, S., Djajasudarma, F., Caturwati, E., Meilinawati, L. (2013: 46) mengatakan bahwa makna dalam pemahaman kontektual adalah sesuatu yang terjadi dalam interaksi subjek dan objek, sehingga ditemukan hal-hal baru setelah pengamatan secara mendalam terhadap objek tersebut. Masa kini, masyarakat kurang responsif terhadap pertunjukan Indang karena hampir tidak ada kebaruan dari bentuk dan strukturnya. Selain itu, struktur juga tidak konsisten menetapkan bagian-bagian yang akan diulang dalam pertunjukan tersebut. Menurut Bakarudin yang diwawancara pada

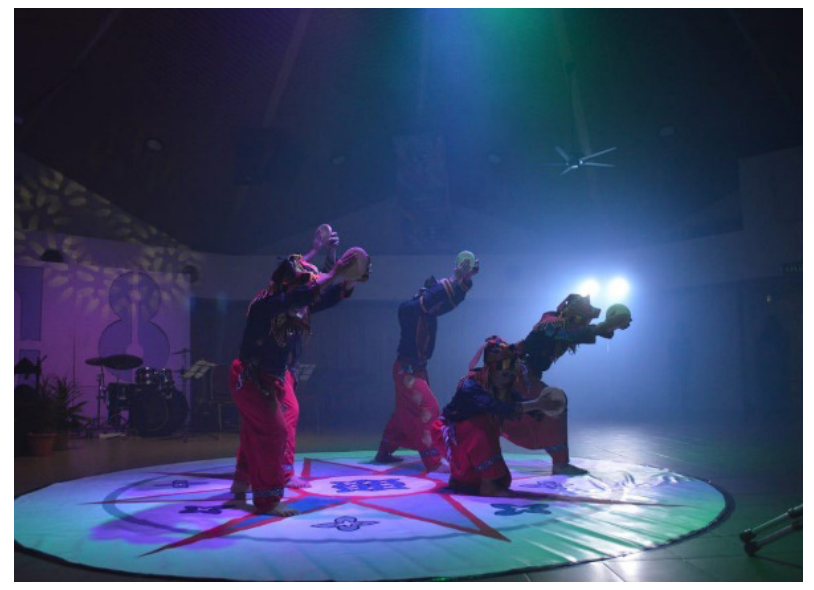

Gambar 3. Tari Indang. (Dokumentasi: Indrayuda) 
tanggal 25 Maret 2017, bagian klimaks dan penyelesaian hampir tidak jelas transisinya, namun bagian klimaks sering tidak menjadi klimaks. Karena itu, pertunjukan Indang kurang menarik untuk menjadi komoditi industri hiburan.

Tampak bahwa di dalam struktur pertunjukan Indang kurang memuat bagianbagian prolog dan besaran porsinya, dan bagian awal, serta bagian yang ditonjolkan, sehingga bagian penonjolan terkadang terlalu singkat durasinya. Bahkan, ditinjau secara bentuk, bagian klimaks kurang atraktif dibandingkan dengan bagian awal. Pengamatan ini menunjukkan bahwa dalam struktur garapan Indang tradisi yang dipertunjukan tersebut, sering tidak ada kejelasan bentuk dari masing-masing bagian dari struktur tersebut. Masing-masing bagian sepertinya hampir sama kekuatannya, sehingga desain dramatiknya tidak jelas. Sebagaimana Vortixa, O., Agustina, A., dan Nursaid, N (2012:566) mengatakan bahwa sebagai kesenian yang terdiri dari unsur gerak (tari), musik, dan sastra, semestinya seniman kesenian Indang menggarap dengan jelas dalam strukturnya ketiga unsur tersebut dengan artistik dan estetis yang dinamis, sehingga menonjokan keunikan yang mampu membuat takjub bagi penonton masa kini sebagai bagian dari pasar industri hiburan.

Aspek bentuk memang kurang bervariasi dalam pertunjukan kesenian Indang tradisi di Padang Pariaman. Pembenahan hanya terbatas pada kostum, sementara teknik muncul, gerak, motif rythm, irama dan melodi serta tata rias maupun ornamen kostum belum banyak yang dikembangkan saat ini. Hal ini berdampak pada lemahnya minat para konsumen industri hiburan untuk menjadikan kesenian Indang sebagai komoditi industri di Padang Pariaman atau Sumatera Barat.

Kesenian Indang terlalu terpaku pada penggarapan sastra atau syair yang dilagukan, karena dalam pertunjukan parade Indang tigo jerong (tigo sandiang) peranan pantun yang saling menyindir adalah sebuah kompetisi. Oleh sebab itu, fokus dalam pertunjukan Indang lebih terkonsentrasi pada masalah syair dari pada aspek bentuk yang tampak secara visual. Permasalahan ini menjadi berlarut-larut sampai saat ini dalam kelompok kesenian Indang di Padang Pariaman.

Secara bentuk motif gerak dan ritme banyak pengulangan di dalam garapan kesenian Indang tradisi yang dipertunjukan dalam berbagai acara seperti acara alek nagari di Padang Pariaman. Irama pertunjukan yang dimainkan meskipun dapat dikatakan dinamis, namun selalu berulang dalam bentuk yang sama, sehingga kesamaan bentuk menimbulkan rasa monoton, dan kurang variasi. Indrayuda (2012: 41) menjelaskan bahwa sebuah karya seni seperti tari dapat tercipta melalui pesiapan yang matang, bersumber dari kinetetis atau unsur seni yang ada seperti gerak, kostum, dan musik yang telah ada sebelumnya, untuk kemudian dikembangkan dan disusun dalam satu rangkaian komposisi yang utuh. Oleh sebab itu, seniman meningkatkan kepekaannya dengan menggunakan sumber garapan yang telah ada di sekitarnya. Dengan demikian persoalan pada struktur garapan kesenian Indang adalah pada persoalan kepekaan yang belum muncul dari senimannya.

Persoalan lain dari aspek garapan bentuk adalah bahwa pemilihan aktor tukang dikia dan tukang aliah banyak saat ini yang kurang memilki teknik vokal atau suara yang baik. Kesan yang terdengar adalah suara yang kurang harmonis. Semestinya tukang dikia dan tukang aliah dipilih dari aktor yang bersuara merdu atau yang teknik vokalnya bagus, di samping mampu mengarang pantun secara spontan karena kemampuan teknik vokal dapat mempengaruhi imajinasi penonton. Jika seorang tukang aliah dan tukang dikia memiliki kemampuan teknik suara yang baik, melodi pantun atau irama pantun yang dia lagukan akan menambah estetis pertunjukan kesenian Indang tersebut.

\section{Idealisme Seniman dan Komunitas Pemilik Kesenian Indang Tradisi}

Secara tradisi, kesenian Indang di Padang Pariaman adalah milik masyarakat nagari 
(desa) serta milik niniak mamak (kalangan adat dan budaya). Dengan demikian, kesenian Indang meskipun belum berkembang secara kualitas dan belum sepenuhnya memenuhi kriteria industri hiburan, kesenian tersebut tidak akan punah dari keberadaannya sebagai warisan budaya masyarakat Padang Pariaman. Kondisi disebabkan oleh adanya fanatisme dan idealisme yang kuat dari seniman serta komunitas pengelola kesenian Indang tersebut.
Di satu sisi, mereka mampu mempertahankan kesenian Indang sebagai salah satu warisan budaya masyarakat Padang Pariaman di berbagai nagari (desa), tetapi dari sisi lain, nilai jual untuk komoditi hiburan kesenian Indang terpinggirkan. Seniman Indang memiliki rasa percaya diri dan fanatisme yang tinggi terhadap nilai artistik, estetis dan nilai budaya dari kesenian Indang tersebut. Para seniman tradisi dan pengelola dari kesenian

Tabel 1. Data permasalahan struktur dan bentuk kesenian Indang.

\begin{tabular}{|c|c|c|c|}
\hline No & Struktur & Permasalahan & Bentuk \\
\hline & duksi & $\begin{array}{l}\text { Kurang jelas motif dan isian } \\
\text { dari bagian introduksi, ter- } \\
\text { kadang sebentar saja. }\end{array}$ & Motif Rithem \\
\hline & an Awal & $\begin{array}{l}\text { Bagian awal sering berulang- } \\
\text { ulang, dan tidak konsisten. }\end{array}$ & Motif Gerak \\
\hline & an Tengah & $\begin{array}{l}\text { Bagian tengah terkadang } \\
\text { lebih banyak syair, dari pada } \\
\text { keseimbangan antara gerak, } \\
\text { rithem dan syair. }\end{array}$ & Motif Kostum \\
\hline & aks & $\begin{array}{l}\text { Tidak jelas, terkadang malah } \\
\text { lebih menonjol bagian tengah } \\
\text { dari pada penonjolan atau kli- } \\
\text { maks. }\end{array}$ & $\begin{array}{l}\text { Motif dan Bentuk } \\
\text { Tata Rias }\end{array}$ \\
\hline & g/Penyelesaian & $\begin{array}{l}\text { Penyelesaian seperti tidak } \\
\text { jelas, terkadang tiba-tiba saja. }\end{array}$ & Irama/Melodi \\
\hline
\end{tabular}

6.

7.

8.

9.

10.

11.

12.
Teknik Suara

Isi Syair

Teknik Muncul Pemain

Teknik Keluar Pemain

Dinamik

Ekspresi

Dramatik
Permasalahan

Terlalu berulang, kurang variasi saat pengulangan.

Sederhana, dan kurang banyak jumlah gerakannya, gerakan tidak menjadi fokus garapan. Kostum sudah berwarna warni, tetapi pemilihan warna kurang harmoni, tataan kostum kurang ornamen dan sederhana dalam garapan motif ornamen.

Jarang menggunakan tata rias, sehingga apabila disorot lampu akan menjadi pucat dan kelabu wajah pemain Indang. Melodi terlalu berulang dan monoton, hanya iramanya itu- ke itu saja yang diulang, kurang variasi dan aksen, bahkan tidak ada improvisasi.

Lemah, teknik suara banyak dari tukang aliah dan dikia yang diolah vokalnya.

Isi syair sudah bagus, tetapi terlalu kondisional, tidak ada yang baku, dan harus menyelipkan unsur generasi muda. Pemain tidak memiliki nilai entertainmen dalam muncul ke panggung.

Kasus yang sama pada teknik keluar malah agak berserakan. Belum ada penataan dinamik yang lebih membuat takjub. Pertunjukan lebih monoton. Ekspresi dari pemain banyak yang datar, hampir ratarata pemain memperlihatkan mimik wajah yang datar saja. Tidak adanya tanjakan yang jelas, meski ada tetapi tidak tampak mana yang klimak dan mana yang bagian tengah. 
Indang berupaya untuk mempertahankan idiom dan struktur yang mapan serta caracara penyajian yang telah mereka warisi dari nenek moyang mereka sebelumnya. Hal itu mempersulit upaya banyak seniman luar mengalami hambatan dalam memodifikasi atau memasukan unsur akulturasi pada kesenian Indang tradisi tersebut. Hal tersebut terjadi di nagari (desa) tersebut, seperti nagari Sungai Garinggiang, Sungai Limau, Patamuan, Tandikek, Sintuak, dan Pincuran Sonsang.

Jannah (2016:3) mengatakan bahwa idealisme yang berbentuk etnosentrisme dari sebuah komunitas, seperti komunitas kesenian Indang di Padang Pariaman, cenderung menaruh streotip negatif terhadap orang di luar komunitasnya. Mereka menganggap bahwa kelompok lain di luar kelompoknya merupakan suatu ancaman, atau lebih rendah dari kelompoknya. Bahkan individu atau kelompok di luar komunitas mereka adalah orang-orang yang akan melemahkan identitas mereka, dan merusak tatanan yang telah dibangun. Kebenaran dari kebudayaan mereka, dari sudut pandang mereka secara intuitif adalah suatu kebenaran. Dengan demikian, sampai saat ini sulit mengubah idealisme seniman dan komunitas kesenian Indang tradisi di berbagai nagari (desa) saat ini di Padang Pariaman.

Persoalan idealisme seniman Indang tradisi didukung pula oleh hegemoni niniak mamak dan elit adat yang memelihara keberadaan kesenian tersebut. Pada gilirannya, kekuasaan yang diberikan oleh elit adat dan niniak mamak pada seniman lokal dan pengelolanya menjadi kekuatan bagi seniman untuk membudayakan idealismenya dalam kesenian Indang. Pada akhirnya kesenian Indang tetap bertahan dengan pandangan dan pemikiran lama sehingga garapan kesenian Indang bagi sebagian besar masyarakat Padang Pariaman dianggap tidak relevan lagi sebagai seni hiburan rakyat.

Kesenian tradisi di Pariaman seperti di daerah Kapalo Hilalang, yaitu Ulu Ambek adalah kesenian yang dikawal oleh elit adat, artinya pemilik kesenian tersebut adalah para pemangku adat dan niniak mamak, yang diserahkan kemudian kepada anak muda untuk memainkannya (Kamal. Z, 2012: 48). Seperti halnya juga Indang, rasa kepemilikan yang tinggi dari para elit adat dapat mempengruhi pola pikir dan idealisme seniman tersebut. Dengan demikian, kesenian seperti Indang tidak dapat begitu saja berubah tanpa persetujuan berbagai pihak dari elemen masyarakat di Padang Pariaman.

Dampak dari dukungan para elit adat terhadap seniman Indang berakibat pada idealisme seniman. Idealisme ini menyangkut masalah bentuk dan struktur serta tata cara dari pertunjukan kesenian Indang. Akibat dari idealisme seniman ini, sulit bagi masyarakat yang memiliki selera seni hiburan untuk memberikan kritisi terhadap pertunjukan kesenian Indang agar dapat digunakan untuk industri hiburan dan kepariwisataan di Sumatera Barat.

Pada gilirannya, kesenian Indang menjadi seni yang eksklusif yang hanya berkisar di dalam wilayah komunitas atau yang hanya digunakan saat ini di kalangan terbatas saja. Artinya, dampak dari idealisme dan fanatisme yang berlebihan dari seniman Indang saat ini berakibat pada terpinggirkannya kesenian tersebut oleh masyarakat yang berorientasi hiburan. Oleh sebab itu, para pengelola industri hiburan jarang menggunakan kesenian Indang tradisi sebagai sarana hiburan wisatawan, dan masyarakat umum, baik di Padang Pariaman dan Sumatera Barat.

\section{Penutup}

Struktur pertunjukan kesenian Indang Tradisi sudah terbentuk secara metodik, yaitu sudah ada prolog atau introduksi, bagian awal, bagian tengah yang menjadi pusat perhatian, klimaks atau penonjolan, dan penyelesaian. Semua bagian dari struktur tersebut terdapat dalam semua garapan kesenian Indang tradisi di Padang Pariaman saat ini.

Permasalahan yang ada pada struktur dan bentuk pertunjukan Indang Duduak adalah struktur yang tidak terangkai dengan rapi antara satu bagian dengan bagian yang lain. Selain itu, bagian klimaks terkadang lebih 
lemah dari pada bagian awal. Selain itu, sering terjadi pengulangan bagian demi bagian yang ada. Permasalahan tersebut sebenarnya mampu diurai jika masyarakat pemiliknya bersedia menerima perbaikan dari anggota masyarakat di luar komunitasnya.

Idealisme seniman memunculkan masalah pada bentuk dan struktur kesenian Indang Tradisi. Selain itu, adanya gerak tari yang kurang variasi, irama musik yang monoton, warna kostum yang belum tertata baik, ornamen kostum belum lengkap, dinamika dan dramatika belum tergarap, sehingga membuat jemu penonton. Artinya, idealisme seniman yang terlalu fanatik berdampak pada terpinggirnya kesenian Indang dari industri hiburan. Selain pula tidak diijinkannya "orang luar" mengembangkan bentuk dan struktur kesenian Indang Tradisi. Dengan demikian, rasa fanatisme dan idealisme seniman maupun dari pengelola kesenian Indang di berbagai nagari (desa) di Padang Pariaman telah merugikan eksistensi kesenian Indang. Artinya, kesenian Indang tidak mampu mengembangkan dirinya, sehingga masyarakat sekitar tidak mendapatkan manfaat yang besar dari keberadaan kesenian tersebut yang sebenarnya adalah milik bersama mereka.

\section{Kepustakaan}

Asriati, A. 2016. Pandangan Pemangku Adat Terhadap Tari Pasambahan di Kota Padang. Humanus, 15(1).

Andriani, T. 2012. Pantun Dalam Kehidupan Melayu (Pendekatan historis dan Antropologis). Jurnal Sosial Budaya, 9(2).

Cauto, Nasbahri dan Indrayuda. 2013. Pengantar Sosiologi Seni. Padang: UNP Press.

Desfiarni, D. 2013. Tinjauan Estetika Tari Piriang Jorong Limau Sundai Pasir Talang Solok Selatan. Humanus, 12(2).

Ediwar. 2010. Kesenian Indang dalam Konteks

Budaya Rakyat Minangkabau. Jurnal Aswara, Jun 2010.

Efrida, E. 2016. Toleransi Masyarakat
Minangkabau Terhadap Peran Perempuan dalam Aktivitas seni Budaya. Gelar, 7(2). Efrida, E. 2016. Estetika Minangkabau dalam Gerak Tari Bujang Sembilan. Ekspresi Seni, 18(1).

Hardi, H. 2015. Karakteristik Karya Tari Syofiani dalam Berkreativitas Tari Minangkabau di Sumatera Barat. Ekspresi Seni, 17(1).

Indrayuda, I. 2012.Eksistensi Tari Minangkabau dalam Sistem Matrilinial dari Era Nagari, Desa dan Kembali ke Nagari . Padang: UNP Press

Indrayuda. 2013. Tari Sebagai Budaya dan Pengetahuan. Padang: UNP Press.

Jannah, Nurul. 2016. Hubungan Etnosentrisme dengan Prasangka. Skripsi. Malang: Universitas Muhammadiyah Malang.

Kamal, Z. 2012. Eksistensi Seni Pertunjukan Luambek dalam Kehidupan Masyarakat Nagari Kepala Hilalang Kecamatan 2 X 11 Kayu Tanam Kabupaten Padang Pariaman.. Wacana Etnik, 3(1).

Rustiyanti, S., Djajasudarma, F., Caturwati, E., \& Meilinawati, L. 2013. Estetika Tari Minang dalam Kesenian Randai Analisis TekstualKontekstual. Panggung, 23(1)

Sari, K. M., Asriati, A., \& Darmawati, D. 2013. Struktur Gerak Tari Tupai Jonjang Di Kanagarian Lumpo Kecamatan IV Jurai Kabupaten Pesisir Selatan. Jurnal Sendratasik, 2(1).

Subagyo, H. 2016. Visualisasi Garap Cerita dan Struktur dalam Tari Wireng di Mangkunegaran. Greget, 9(1).

Sutiyono, S. 2010. Manajemen Seni Pertunjukan Kraton Yogyakarta Sebagai Penanggulangan Krisis Pariwisata Budaya. Bahasa dan Seni, 38(2).

Syahrial, S. 2016. Guna dan Fungsi Tari Piring Padang magek Sumatera Barat. Greget, 12(2).

Vortixa, O., Agustina, A., \& Nursaid, N. 2012. Struktur Lirik Nyanyian Indang di Nagari Kuranji Hulu Kecamatan Sungai Geringging Kabupaten Padang Pariaman. Pendidikan Bahasa dan Sastra Indonesia, 1(1). 